\title{
EKSPLORASI IDENTITAS DIRI DAN PERAN PADA KAKEK-NENEK SEBAGAI CAREGIVER DARI ANAK DENGAN DISABILITAS
}

\author{
Dinie Ratri Desiningrum ${ }^{1,2}$, Suryanto ${ }^{1}$ \\ ${ }^{1)}$ Fakultas Psikologi Universitas Airlangga \\ J1. Airlangga 4-6, Kampus B Unair, Surabaya, Indonesia, Indonesia \\ ${ }^{2)}$ Fakultas Psikologi Universitas Diponegoro \\ J1. Prof. Soedharto SH, Tembalang, Semarang, Jawa Tengah, Indonesia \\ dn.psiundip@gmail.com
}

\begin{abstract}
Being grandparents is an important role and valued in the family in which family members have a certain view of the existence of grandparents in the family especially about what will be taught to their grandchildren. When grandchildren have disability, grandparents form a special expectation of themselves and grandchildren resulting on adjustment in the interaction process with grandchildren. This study aims to explore how the interaction between grandparents and grandchildren with disabilities can influence the formation of self-identity and the role of grandparents in the family. The study used a qualitative method, semi-structured interviews were conducted on 10 grandparents of children with intellectual and/or physical disabilities located in Semarang, Central Java, obtained through purposive sampling techniques. An Interpretative Phenomenology Analysis resulted in three main themes, namely: the formation of a grandfather's self-identity, the role of grandparents, and the assessment of the development of their grandchildren. The results highlight the important role of grandparents when a child has a disability, which illustrates that the grandparents' experience and role in the family vary, depending on the child's disability and the context of each family.
\end{abstract}

Keywords: self-identity; role; grandparents; family; children with disability

\begin{abstract}
Abstrak
Menjadi kakek-nenek adalah peran yang penting dan dihargai dalam keluarga di mana anggota keluarga memiliki pandangan tertentu terhadap keberadaan kakek-nenek dalam keluarga khususnya tentang apa yang akan diajarkan kepada cucu mereka. Ketika cucu mengalami disabilitas, pada kakek-nenek terbentuk harapan khusus terhadap diri dan cucu dan terjadi penyesuaian diri dalam proses interaksi dengan cucu. Penelitian ini bertujuan untuk mengeksplorasi bagaimana interaksi antara kakek-nenek dengan cucu disabilitas dapat mempengaruhi pembentukan identitas diri dan peran kakek-nenek dalam keluarga. Penelitian menggunakan metode kualitatif, wawancara semi-terstruktur dilakukan terhadap 10 kakek-nenek dari anak-anak dengan disabilitas intelektual dan/atau fisik yang berada di Semarang, Jawa Tengah, diperoleh melalui teknik sampling purposif. Analisis dengan IPA menghasilkan tiga tema utama, yaitu: pembentukan identitas diri kakek-nenek, peran kakek-nenek, dan penilaian terhadap perkembangan cucunya. Hasilnya menggarisbawahi peran penting nenek ketika seorang anak memiliki disabilitas, yang menggambarkan bahwa pengalaman nenek dan perannya dalam keluarga bervariasi, tergantung pada disabilitas anak dan konteks keluarga masing-masing.
\end{abstract}

Kata Kunci: identitas diri; peran; kakek-nenek; keluarga; anak dengan disabilitas

\section{PENDAHULUAN}

Kelahiran seorang anak dalam keluarga, menyebabkan adanya kakek-nenek, dan terbentuklah hubungan di dalam keluarga dan lintas generasi. Menjadi kakek-nenek merupakan suatu harapan yang dinantikan, terdapat fase 'ritus peralihan' pada usia dewasa, dimana jika individu berumur panjang, maka ia bisa menjadi kakek-nenek selama kurang lebih sepertiga dari masa hidupnya (Rosenbaum, 2016). Meskipun cukup banyak penelitian yang mengeksplorasi pengalaman kakek-nenek dalam membesarkan cucu (Downie, Hay, Horner, Wichmann, \& Hislop 2010; Dunne \& Kettler 
2007), namun pengetahuan masyarakat mengenai harapan lansia sebagai kakeknenek, interaksi dan peran yang sebenarnya dimainkan dalam kehidupan keluarga, masih terbatas hasil penelitiannya, khususnya mengenai hubungannya dengan cucu berkebutuhan khusus.

Kakek-nenek menjadi sumber pendukung pengasuhan cucu yang semakin penting, meskipun merawat cucu mungkin memiliki konsekuensi kesehatan yang negatif bagi kakek-nenek (Di Gessa, Glaser, \& Tinker, 2016). Kakek-nenek masih sering memainkan peran penting dalam mempertahankan kehidupan keluarga dan memberikan dukungan sosial, seperti dalam pengasuhan anak, bantuan keuangan, dukungan emosional untuk anak-anak dan cucu-cucu mereka, memfasilitasi komunikasi dan hubungan antar keluarga, dan kakek-nenek ini juga bisa berperan sebagai caregiver dari cucunya (Davey, Savla, Janke, \& Anderson, 2009).

Caregiver adalah individu yang membantu anak dalam menjalani kehidupan sehari-hari, seperti mandi, berpakaian, dan makan, menemani bermain, termasuk membantu dalam proses terapi; serta turut memperhatikan kesehatan anak (Hens, 2016). Caregiver bisa terdiri dari para orangtua, extended family seperti kakek-nenek, maupun orang-orang yang tidak memiliki ikatan darah seperti baby sitter dan perawat anak. Dalam studi ini, peneliti fokus pada caregiver kakeknenek, mengingat kultur di Indonesia yang tergolong kolektivisme dan masih memasangkan kakek-nenek dalam pengasuhan anak (Hofstede, Hofstede, \& Minkov, 2010).

Hubungan kakek-nenek dan cucu adalah unik, dengan semakin banyaknya kakek-nenek menghargai kesempatan untuk menjalin hubungan hangat dengan cucu, untuk mengajar generasi berikutnya, seperti dalam suatu hasil penelitian yang menegaskan bahwa kakek-nenek memainkan peran utama dalam pendidikan cucu (Smorti, Tschiesner, \& Farneti, 2012). Prevalensi dan intensitas keberadaan kakek-nenek yang meningkat di seluruh dunia telah menarik perhatian pada implikasi kesehatannya bagi lansia pengasuh. Berkat harapan hidup yang lama dan mengurangi kematian bayi, keluarga besar yang terdiri dari empat generasi, tinggal bersama atau tidak, jumlah kakek-nenek di dunia ini akan semakin bertambah dan perlu diperhatikan. Hasil penelitian menyebutkan bahwa kakek-nenek yang merawat cucu memiliki kesehatan mental dan fisik yang lebih baik, dibandingkan dengan nonpengasuh $(\mathrm{Xu}, 2018)$.

Keberadaan kakek-nenek dapat bervariasi baik di dalam maupun di luar keluarga, sebagai fungsi dari keadaan sosial, historis, keluarga, dan individu yang unik. Kualitas hubungan dengan cucu-cucu menjadi paling berpengaruh dan berhubungan secara positif dengan kepentingan peran kakek-nenek yang dirasakan (Mahne, \& Klingebiel, 2012). Dalam menikmati peran sebagai kakeknenek, orang dewasa madya melihat tahap kehidupan di kemudian hari ini sebagai kesempatan untuk mencapai kehidupan pribadi dan impian pensiun yang mungkin mereka tunda karena komitmen keluarga dan pekerjaan. Hasil suatu riset diantaranya menyebutkan bahwa menjadi sehat di usia tua, dan menikmati hari-hari dengan tetap bermanfaat adalah impian setiap lansia, daripada mengalami demensia dan membebani orang-orang di sekitarnya (Gitlin, Winter, Dennis, Hodgson, \& Hauck, 2010)

Ketika seorang anak dilahirkan dengan suatu disabilitas, bagaimanapun, kakek-nenek seringkali merupakan sumber dukungan yang penting bagi keluarga mereka melalui situasi yang tak terduga, penuh emosi dan penuh tekanan ini. Di Australia, satu dari delapan keluarga memiliki setidaknya satu anak dengan disabilitas intelektual atau perkembangan yang tinggal di rumah, dengan kecerdasan intelektual (59\%) dan sensorik / wicara (53\%) adalah yang paling umum (Australian Bureau of Statistics, 2015). Terdapat fakta bahwa $10 \%$ dari pengasuh utama di Australia adalah kakek-nenek dari 
anak yaitu memberikan bantuan yang signifikan dan berbagi dalam tanggung jawab (ABS, 2015). Dalam suatu penelitian lain terhadap anak-anak dengan obesitas, ditemukan bahwa kakek-nenek cukup berperan dalam mencegah perilaku terkait obesitas anak ini, dapat disimpulkan bahwa kakek-nenek masih dibutuhkan pengasuhannya dan dukungannya terhadap keluarga (Bell, Perry, \& Prichard, 2018, He, Li, \& Wang, 2018). Kakek-nenek disebut sebagai pemberi dukungan emosional dan memberi nasihat, seperti dalam suatu hasil penelitian bahwa terjadi suatu interaksi dan proses komunikasi selama sesi Keterlibatan Media Bersama (Joint Media Engagement - JME) yang melibatkan kakek-nenek dan anak-anak (besar) dalam penggunaan kolaboratif tablet, sehingga kedekatan emosional ini membuat cucu lebih mau men-dengarkan kakek-nenek daripada orang lain (Amaro, Oliveira, \& Veloso, 2016).

Hingga saat ini, hanya segelintir penelitian yang secara langsung menggali perspektif kakek-nenek tentang pengalaman dan peran mereka ketika memiliki cucu disabilitas. Ibu yang merupakan pengasuh utama anak-anak penyandang disabilitas mengalami lebih banyak masalah kesehatan mental daripada ibu dari anak-anak normal. Hasil penelitian terhadap 72 ibu dari lembaga disabilitas nonpemerintah Australia, menemukan bahwa kakek-nenek adalah sumber dukungan penting bagi ibu dari anak-anak penyandang disabilitas, di mana ibu yang kurang mendapat dukungan dari orangtua mereka sendiri sangat rentan mengalami stres. Dokter harus secara aktif memfasilitasi keterlibatan kakeknenek (Crettenden, Lam, \& Denson, 2018). Di samping itu, grandparental dalam keluarga dapat meningkatkan kesehatan dan kesejahteraan anak (Snopkowski \& Sear, 2015). Dalam suatu penelitian lainnya, ditemukan pula bahwa kakek-nenek memiliki efek langsung pada prestasi cucu-cucu, salah satu penjelasannya adalah bahwa cucucucu dapat mengambil manfaat dari sumber daya budaya yang diberikan kakek-nenek kepada mereka (Bol, \& Kalmijn, 2016).
Hasil riset yang pernah peneliti lakukan, mengenai hubungan antara peran kakeknenek dalam keluarga dan kesejahteraan psikologis lansia yang ikut mengasuh cucu dengan autism spectrum disorder (ASD), memperoleh hasil bahwa peran lansia dalam keluarga diantaranya adalah sebagai penyedia bantuan psikologis, instrumental dan emosional, berupa merawat anak ketika orangtua tidak di rumah, membantu biaya terapi, menemani bermain dan merawat ketika sakit (Desiningrum, 2018). Kedekatan kakek-nenek dengan cucunya, memberikan suatu persepsi tertentu mengenai peran kakeknenek, dan membentuk identitas diri lansia. Dari hasil survei terhadap 98 anak usia 11-13 tahun, terdapat gambaran sifat dan frekuensi kontak anak dengan kakek-nenek, dan jenis kegiatan yang biasa dilakukan bersama, disebutkan bahwa sekitar 40 persen dari siswa memiliki kontak harian atau mingguan dengan kakek-nenek, sepertiga "secara teratur melakukan hal-hal bersama-sama", dan seperlima mengatakan mereka memiliki "hubungan khusus" dengan kakek-nenek, dan semua persepsi cucu membentuk identitas peran dari kakek-nenek (Keeling, 2012).

Suatu penelitian di Cina, menyebutkan bahwa kakek-nenek menjadi bagian integral dari proses membesarkan cucu dan kehidupan keluarga. Namun, kakek-nenek terlibat dalam berbagai perannya dengan berorientasi pada cucu (misalnya, dalam bermain, berkegiatan sosial dan seremonial) sekitar dua kali lebih sering daripada peran yang berorientasi pada orangtua (misalnya, pengasuh bayi, pemberi dukungan instrumental, penyedia bantuan keuangan, menemani proses intervensi medis dan terapeutik anak) (Goh, 2009).

Ada sedikit keraguan bahwa kakek-nenek adalah dukungan penting bagi orang tua dan memainkan peran penting dalam kehidupan cucu mereka. Misalnya, Nybo, Scherman, dan Freeman (dalam Woodbridge, Buys, \& Miller, 2011) mengeksplorasi peran kakeknenek dalam keluarga yang memiliki seorang anak tuli, kemudian memeriksa enam sistem keluarga di North Dakota mengenai 
perspektif masing-masing dari tiga generasi (cucu, orang tua, dan kakek-nenek). Mereka menemukan bahwa meskipun dinamika dan keadaan keluarga, seperti jarak geografis dan keuangan yang terbatas, tampaknya ada pemahaman kuat yang tidak terucapkan bahwa kakek-nenek 'membantu' pada saatsaat stres. Margetts, Le Couteur, \& Croom (2006) mewawancarai enam kakek-nenek dari anak-anak Inggris dengan autisme dan mengidentifikasi adanya tiga tema kunci untuk menjelaskan pengalaman: ikatan orangtua (dalam merawat anak dan cucu), menerima diagnosis (berjuang dengan diagnosis) dan menjaga keutuhan keluarga (merasa bertanggung jawab atas keluarga yang lebih luas). Di Australia, Woodbridge, Buys, dan Miller (2009) mendokumentasikan bagaimana 22 kakek-nenek dari anak-anak dengan berbagai macam disabilitas mengkonseptualisasikan pengalaman sebagai 'rollercoaster emosional', namun ada temuan bahwa terdapat kebanggaan yang signifikan dalam seberapa baik keluarga mampu menyesuaikan diri dengan tantangan dari situasi. Kakek-nenek mendukung keluarga melalui masa-masa krisis tersebut.

Beberapa penelitian telah mengeksplorasi pengalaman, makna, atau interaksi kakeknenek dengan cucu-cucu mereka, serta perannya dalam kehidupan cucu-cucu dengan disabilitas (seperti: Reitzes \& Mutran, 2004). Beberapa dekade yang lalu, melalui wawancara dengan 70 pasang kakek-nenek tentang interaksi mereka dengan cucu-cucu pra-remaja, Neugarten dan Weinstein (dalam Woodbridge dkk., 2011) me-ngembangkan tipologi klasik mereka dari lima peran kakeknenek, yaitu: formal, menyenangkanmencintai, jauh, sumber kebijaksanaan keluarga dan orangtua pengganti. Peran 'formal' menekankan menghormati batas dan peran orangtua, 'jauh' berarti keterlibatan hanya pada hari-hari seremonial dan khusus (misalnya: ulang tahun), 'menyenangkanmencintai' berarti menghindari otoritas dan fokus pada persahabatan, 'sumber kebijaksanaan keluarga' yaitu sejarawan keluarga dan meneruskan kearifan keluarga, sementara 'orangtua pengganti' berarti memenuhi kebutuhan cucu ketika orangtua tidak mampu.

Baru-baru ini, dalam studi longitudinal tiga tahun terhadap 300 kakek-nenek dan cucucucu, Kornhaber (dalam Villar, 2015) membangun peran ini untuk mengembangkan beberapa teori yang menjelaskan grandparenting, yaitu: Grandparent Drive (GD), Latent Grandparent Identity (LGI) dan Functional Grandparent Identity (FGI). Grand-parenting Drive (GD) adalah apa yang mendorong kakek-nenek untuk membangun dan menjaga hubungan dengan cucu-cucu, baik secara emosional dan fisik. Kornhaber mendeskripsikan GD dalam bentuk "dorongan biologis utama yang mengakar" yang menjelaskan mengapa kakek nenek merasa begitu terdorong untuk memelihara dan memperhatikan kebutuhan emosional dan fisik cucu mereka. LGI, yang berkembang sepanjang hidup seseorang, paling baik dikonseptualisasikan sebagai harapan dan keyakinan "teoretis" individu tentang peran kakek-nenek, sementara FGI adalah gaya dan perilaku sebenarnya yang diadopsi oleh kakek-nenek setelah kelahiran cucu. LGI berkembang sepanjang hidup seseorang dan dipengaruhi oleh pengalaman mereka sendiri, baik positif maupun negatif, kepribadian mereka, persepsi mereka dan pengaruh masyarakat. FGI dapat diamati dengan meninjau peran dan tanggung jawab yang dilakukan oleh kakek-nenek dalam keluarga mereka, misalnya kakek-nenek yang memiliki "peran mencari kesenangan" akan terlibat dalam kegiatan menyenangkan dengan cucucucu mereka (misalnya, bermain, olahraga, pergi piknik dan meng-unjungi tempat-tempat hiburan), sementara kakek-nenek yang memberlakukan "peran kebijaksanaan keluarga" dapat memastikan tradisi keluarga terus berlanjut, seperti perayaan ulang tahun dan hari besar agama (Falk \& Falk, 2002). FGI dapat bervariasi antar keluarga karena perbedaan dalam tradisi keluarga, pengalaman dan kondisi keluarga tersebut bisa akibat perceraian sehingga kakek-nenek mengambil peran 'orangtua pengganti' sementara, atau suatu kondisi kakek-nenek 
menjalani pensiun yang juga berpengaruh terhadap FGI (Szinovacz \& Davey, 2006).

Maka kelahiran seorang anak penyandang disabilitas mungkin mempengaruhi identitas kakek-nenek, dan hal ini belum banyak diteliti. Yang banyak terjadi adalah bahwa mayoritas generasi kakek-nenek saat ini akan memiliki pengalaman terbatas dengan disabilitas di mana anak-anak penyandang disabilitas distigmatisasi, dan dikeluarkan dari keluarga mereka untuk menghabiskan hidup mereka di lembaga-lembaga. Dari suatu penelitian, disebutkan bahwa kakek-nenek dari ibu yang mengalami konflik dalam hubungan dengan anak berisiko dijauhkan dari cucu mereka, maka untuk beberapa kondisi, tidak semua lansia bisa dekat dengan cucu mereka, seperti pada anak dengan disabilitas (Sims \& Rofail, 2013).

Meskipun sikap masyarakat terhadap disabilitas telah berubah dari waktu ke waktu seiring dengan perkembangan kakek-nenek masa kini dalam memberikan dukungan sosial, hal ini sangat membantu dalam menghadapi tantangan dalam merawat seorang anak dengan disabilitas (Crettenden, Lam, \& Denson, 2018). Dengan demikian, artikel ini berfokus pada peningkatan pemahaman kita tentang pengalaman mereka menjadi kakek-nenek dari seorang anak penyandang disabilitas dan memiliki dua tujuan utama. Pertama, menggunakan peran kakek-nenek klasik Neugarten dan Weinstein's (dalam Woodbridge, Buys, \& Miller, 2011) sebagai dasar awal untuk perbandingan, mengeksplorasi bagaimana kakek-nenek berinteraksi dengan cucu-cucu mereka. Kedua, menggunakan Kornhaber (dalam Villar, 2015) mengenai LGI dan FGI, untuk mengeksplorasi bagaimana pengalaman tersebut dapat mempengaruhi perkembangan dan pengesahan identitas kakeknenek.

\section{METODE}

Penelitian ini menggunakan metode kualitatif dengan pendekatan fenomenologis. Metode penelitian kualitatif bertujuan untuk mendeskripsikan pengalaman yang dialami individu (Smith, Flowers, \& Larkin, 2009). Tujuan penelitian fenomenologi adalah menangkap sedekat mungkin bagaimana fenomena tersebut dialami di dalam konteks terjadinya suatu fenomena (Smith dkk., 2009). Teknik analisis yang digunakan dalam penelitian ini adalah Interpretative Phenomenological Analysis (IPA). Penafsiran dalam IPA memiliki dua tahapan. Tahapan pertama ialah subjek memaknai pengalaman hidupnya dan tahapan kedua, peneliti memaknai hasil pengalaman subjek yang biasa disebut double hermeuneutic (Smith dkk., 2009).

\section{Partisipan}

Dipilih 10 kakek-nenek dengan cucu disabilitas. Berusia antara 60 hingga 75 tahun, dengan tidak mengidap penyakit kronis atau akut. Semua responden berdomisili di Semarang, dan merupakan kakek-nenek dari pihak ibu. Pada saat wawancara, semua cucu berusia di bawah 17 tahun (mulai dari 2 hingga 14) dan kondisi disabilitas cucu adalah cerebral palsy, down sindrome, dan autism spectrum disorder / asperger. Meskipun tingkat keparahan dan penyebab disabilitas berbeda, kakek-nenek menjelaskan sifat dan dampak disabilitas tersebut dapat diukur: sedang hingga berat. Untuk mayoritas anak penyandang disabilitas adalah laki-laki dan terdapat cucu lain yang tidak disabilitas dalam keluarga. Seluruh rincian data sosiodemografis partisipan tercantum di Tabel 1 .

\section{Prosedur}

Peserta direkrut melalui teknik sampling purposive, dan memperoleh informed consent untuk proses wawancara. Lalu pelaksanaan wawancara dilakukan secara individual. Wawancara semi-terstruktur, yang berlangsung selama 60 hingga 90 menit, dilakukan di rumah responden dan mencakup bidang-bidang utama berikut: harapan dan pengalaman dari peran kakek-nenek, ingatan akan pengalaman mereka pada saat diagnosis, hubungan dan kegiatan mereka dengan semua 
cucu mereka. Wawancara direkam dan kemudian ditranskripsikan.

Tabel 1.

Gambaran Sosiodemografis Subjek Penelitian

\begin{tabular}{|c|c|}
\hline Kategori & Jumlah \\
\hline \multicolumn{2}{|l|}{ Jenis Kelamin } \\
\hline Perempuan & 7 \\
\hline Laki-laki & 3 \\
\hline \multicolumn{2}{|l|}{ Usia } \\
\hline 60-65 tahun & 4 \\
\hline $65-70$ tahun & 3 \\
\hline 70-75 tahun & 2 \\
\hline 75 tahun ke atas & 1 \\
\hline \multicolumn{2}{|l|}{ Status Pernikahan } \\
\hline \multicolumn{2}{|l|}{ Menikah (hidup bersama } \\
\hline pasangan) & 7 \\
\hline Janda/Duda & 3 \\
\hline \multicolumn{2}{|l|}{ Latar Belakang Pekerjaan } \\
\hline \multicolumn{2}{|l|}{ Sebelum Pensiun } \\
\hline Guru & 3 \\
\hline Pegawai & 2 \\
\hline Petani/pedagang & 5 \\
\hline \multicolumn{2}{|l|}{ Suku Bangsa } \\
\hline Jawa & 6 \\
\hline Sunda & 3 \\
\hline Batak & 1 \\
\hline \multicolumn{2}{|l|}{$\begin{array}{l}\text { (Jumlah Responden, Usia } \\
\text { dan Jenis Kelamin) }\end{array}$} \\
\hline Cerebral palsy & $\begin{array}{l}2(7 \& 5 \\
\text { thn })(P)\end{array}$ \\
\hline Down sindrome & $\begin{array}{l}3(8,4,7 \text { thn }) \\
(2 \mathrm{P}, 1 \mathrm{~L})\end{array}$ \\
\hline Autism Spectrum Disorder & 5 \\
\hline / Asperger & $\begin{array}{l}(9,8,5,11,13 \\
\text { thn) }(\mathrm{L})\end{array}$ \\
\hline
\end{tabular}

\section{Analisis Data}

Setelah transkripsi, data dianalisis menggunakan Interpretative Phenomenology Analysis (IPA), untuk mengidentifikasi dan mengkategorikan tema-tema dan pola dalam data. Adapun tahapan dalam Interpretative Phenomenology Analysis (IPA) menurut Smith dkk. (2009), yaitu: (1) membaca transkrip berulang-ulang, untuk menemukan maknanya; (2) pencatatan awal (initial noting), untuk memberi komentar-komentar terhadap ucapan subjek (komentar deskriptif, linguistik dan konseptual); (3) mengembangkan tema yang muncul (emergent theme); (4) mengembangkan tema super-ordinat; (5) beralih ke transkrip subjek berikutnya; (6) menemukan pola antarsubjek; (7) mendeskripsikan tema induk.

Peneliti membaca dan membaca kembali transkrip untuk membuat konsep dan mengkategorikan data ke dalam kategori dan tema yang bermakna (Smith dkk., 2009). Data diperiksa secara khusus untuk deskripsi harapan, peran dan interaksi nenek-cucu, khususnya dalam membentuk identitas laten (LGI) dan fungsional (FGI) (Kornhaber, dalam Villar, 2015). Tujuan kedua adalah untuk mengeksplorasi validitas dari lima peran nenek menurut Neugarten dan Weinstein's (dalam Woodbridge dkk., 2011), dengan kategori: formal, menyenangkanmencintai, jauh, sumber kebijaksanaan keluarga dan orang tua pengganti. Analisis dan tipologi ini dipandu oleh teori yang ada (Woodbridge dkk., 2009).

\section{HASIL DAN PEMBAHASAN}

Kakek-nenek secara terbuka mendiskusikan harapan dan persepsi mereka, menggambarkan bagaimana pengalaman disabiltas cucu mempengaruhi peran kakek-nenek dan identitas diri mereka. Tiga tema sentral diidentifikasi dari data, yaitu: pembentukan identitas diri kakek-nenek, peran kakek-nenek dalam keluarga, dan penilaian terhadap cucu disabilitas. Gambaran tema superordinat dan tema induk tersaji dalam tabel 2.

Penelitian ini mengidentifikasi adanya variasi pengalaman kakek-nenek dalam interaksinya dengan cucu disabilitas, sesuai dengan karakteristik subjek. Kakek-nenek menceritakan bahwa terdapat dorongan luar biasa untuk memainkan peran positif dalam kehidupan keluarga dan cucu, memperoleh banyak kesenangan dan kepuasan dari hubungan kakek-nenek-cucu, tanpa memandang disabilitasnya. 
Tabel 2.

Tema yang Dihasilkan

\begin{tabular}{|c|c|}
\hline Tema Induk & Tema Superordinat \\
\hline $\begin{array}{lll}\begin{array}{l}\text { Pembentukan identitas diri } \\
\text { kakek-nenek }\end{array} & & \\
\end{array}$ & $\begin{array}{l}\text { Identitas Laten: } \\
\text { - Diwarnai oleh pengalaman masa lalu } \\
\text { - Menjadi kakek-nenek yang kreatif } \\
\text { - Konsep ideal tentang kakek-nenek yang sukses } \\
\text { membentuk keluarga harmonis } \\
\text { Identitas Fungsional: } \\
\text { - Pendukung anak dan cucu setelah diagnosis } \\
\text { - Fungsi pengasuhan terhadap cucu disabilitas } \\
\text { - Sumber kasih sayang murni terhadap cucu dan keluarga } \\
\text { - Menerima kenyataan, dan mengubah rencana hidup } \\
\text { - Merasa dibutuhkan, sehingga meningkatkan skill } \\
\text { pengasuhan disabilitas } \\
\text { - Terbentuknya kebermaknaan hidup }\end{array}$ \\
\hline $\begin{array}{l}\text { Peran kakek-nenek dalam } \\
\text { keluarga }\end{array}$ & $\begin{array}{l}\text { - Penyedia dukungan sosial bagi keluarga: pemberi } \\
\text { dukungan instrumental, memberi kesempatan pada } \\
\text { orangtua dari cucu untuk self development } \\
\text { - Pemberi kesenangan pada cucu disabilitas: bermain } \\
\text { bersama, penyedia dukungan emosional di waktu-waktu } \\
\text { tertentu } \\
\text { - Sumber kebijaksanaan: mengikuti aturan orangtua dari } \\
\text { cucu disabilitas, tidak banyak menegur anak dan cucu, } \\
\text { mengajak silaturahim }\end{array}$ \\
\hline $\begin{array}{l}\text { Penilaian } \\
\text { disabilitas }\end{array}$ & $\begin{array}{l}\text { - Kesesuaian harapan dan keadaan cucu disabilitas } \\
\text { - Kualitas interaksi antar sibling } \\
\text { - Belajar memahami kondisi disabilitas cucu } \\
\text { - Berusaha tidak membedakan cucu disabilitas dengan cucu } \\
\text { lainnya } \\
\text { - Memahami keterbatasan cucu sesuai keparahan disabilitas } \\
\text { (secara emosional dan praktis) } \\
\text { - Adanya kedekatan dengan cucu disabilitas } \\
\text { - Cucu disabilitas menjadi sumber kasih sayang }\end{array}$ \\
\hline
\end{tabular}

Salah satu pernyataan dari subjek: "Yah..namanya aja eyang, kudu jalan akalnya hehe.... Yang nyuapin sambil main, membacakan cerita, cerita macem-macem...yang anaknya suka aja.. yang penting anteng...”.

Identitas diri kakek-nenek, terdapat banyak harapan yang diwarnai konsep masa lalu tentang kakek-nenek yang ideal, cukup kreatif untuk menciptakan permainan dan kesenangan bagi cucu, dan pada akhirnya membentuk keluarga yang harmonis.
Terdapat pernyataan lain hasil wawancara, yaitu:

"maunya sih semua senang, semua sehat, bahagia... kalau neneknya sehat kan bisa bantu ngurus cucu juga...jadi bisa ikut mendidik anak supaya pinter sama suaminya, sama cucu, berarti kan saya udah berhasil mendidik anak-anak saya...".

Kutipan tersebut menunjukkan bahwa terdapat konsep ideal dari subjek tentang kakek-nenek yang sukses membentuk keluarga harmonis. 
Harapan sesuai dengan konsep menjadi kakek-nenek yang ideal ini, di tengah fakta bahwa mereka memiliki cucu dengan disabilitas, bukan sesuatu yang mudah untuk memenuhinya. Identitas fungsional, sebagai identitas sesuai fakta praktis yang dilakukan responden, terbentuk ketika terdapat suatu berita bahwa hadir seorang anak dengan disabilitas dalam keluarga, dan hal tersebut memberi dampak kritis bagi seluruh anggota keluarga. Maka kehadiran kakek-nenek ini menjadi suatu sumber dukungan psikologis yang signifikan bagi keluarga (Kelley, Whitley, \& Peter, 2011).

Pernyataan subjek lainnya, yaitu:

"saya sih lebih memilih liat cucu sehat, pinter daripada dikasi uang banyak haha....udah itu aja".

"intinya...saya melihat diri saya punya manfaat dalam hidup, bukan sekedar jadi beban keluarga, tapi bisa bantu ngurus cucu, saya ikutan terapi juga jadi ngerti apa yang dibutuhkan cucu saya...yah belajar jadi terapis hehe...".

Dua pernyataan ini melahirkan tema bahwa subjek merasa dibutuhkan, sehingga meningkatkan skill pengasuhan disabilitas, serta terbentuknya kebermaknaan hidup dalam diri subjek.

Subjek memberikan kasih sayang tulus dalam mengasuh cucunya, tanpa membeda-bedakan mengenai keadaan disabilitasnya. Kemudian dalam hal identitas selanjutnya adalah membentuk suatu perasaan keberfungsian diri, mau mengembangkan kemampuan berkomunikasi dan memahami kondisi disabilitas, serta rela berkorban demi cucu dan keluarganya. Mendapat kesempatan untuk tinggal dekat dengan cucu disabilitas dan ikut serta dalam pengasuhan, merupakan hal yang disyukuri oleh kakek-nenek, karena mempermudah proses komunikasi. Seperti pada salah satu hasil riset yang menemukan bahwa terdapat tantangan komunikatif yang dihadapi oleh kakek-nenek jarak jauh (Bangerter \& Waldron, 2014).

Pada akhirnya pada kakek-nenek terbentuk suatu kebermaknaan hidup, dimana hidup menjadi lebih berarti dengan memahami bahwa keberadaan dirinya, dukungan yang diberikannya, membuat cucu disabilitas dan anggota keluarga lainnya mencapai kesehatan fisik dan psikologis (Reitzes, \& Mutran, 2004).

Dari perspektif teoritis, penelitian ini menunjukkan bahwa disabilitas cucu tidak secara signifikan mengubah perkembangan identitas atau gaya dari kakek-nenek. Namun, deskripsi kakek-nenek tentang peran ideal mereka (LGI) dan aktual (FGI), lalu interaksi kakek-nenek dengan cucu, memberikan wawasan unik ke dalam pengalaman seharihari dan memberikan dampak bagi kondisi disabilitas cucu. Banyak kakek-nenek yang tidak tahu tujuan dan harapan tentang membangun hubungan dekat dan melakukan kegiatan menyenangkan dengan cucu-cucu mereka.

Seperti pada kutipan hasil wawancara berikut: "iya..saya dekat dengan cucu saya, kadang suka nemenin main di lantai, selonjoran..... atau keluar ngeliatin naik sepeda"

"ah si X sih, kalo sedih larinya ke saya hehe....misalnya dimarahi mamanya, atau kehilangan barang".

Kedua pernyataan ini menunjukkan bahwa subjek bisa memberikan kesenangan bagi cucunya.

Jadi, LGI subjek ditantang oleh kondisi disabilitas cucu. Namun, terbentuknya FGI yang positif, menunjukkan bahwa kakeknenek berusaha mempertahankan gaya interaksi 'menyenangkan' yang mereka inginkan.

Kutipan hasil wawancara, yaitu: "enggak saya gak marah... kalo ada apaapa dengan cucu ya saya serahkan orangtuanya, kan memang tanggung jawab mereka, saya pastinya kasih saran-saran, tapi tetap mereka yang membuat keputusan",

menunjukkan bahwa subjek bisa menjadi sumber pemberi saran yang bijaksana dalam keluarga. 
Hasil penelitian lainnya menunjukkan bahwa subjek mengakui sering memberikan dukungan instrumental yang penting dalam peran 'pengganti orangtua' sehingga tidak ingin pensiun dari perannya tersebut. Subjek menginginkan agar anaknya, yaitu orangtua dari cucu disabilitas, memiliki waktu untuk mengembangkan dirinya dan membangun kebahagiaan bersama pasangan, sehingga sesekali kakek-nenek menggantikan peran pengasuhan (Smorti, Tschiesner, \& Farneti, 2012).

Kakek-nenek dengan bijaksana mengelola hubungan keluarga, termasuk perbedaan antargenerasi, dalam kaitannya dengan memberi makan cucu, di mana kakek-nenek cukup memprioritaskan makanan yang sehat bagi cucu (Rogers, Bell, \& Mehta, 2019). Kakek-nenek secara filosofis menerima keadaan ini dan memiliki kebanggaan dalam perannya sebagai pendukung utama, dan lebih lanjut menjelaskan bagaimana menjadi kakek-nenek dari seorang anak penyandang disabilitas memaksa mereka untuk mengevaluasi kembali nilai-nilai dan mengesampingkan kepentingan diri pribadi, serta membentuk identitas mereka sebagai kakek-nenek.

Studi ini juga menunjukkan bahwa tipografi klasik Neugarten and Weinstein (dalam Woodbridge, Buys, \& Miller, 2011) dari lima gaya tetap relevan untuk kakek-nenek kontemporer, bahkan ketika cucu memiliki disabilitas. Adanya keterlibatan aktif kakeknenek dalam kehidupan keluarga, menyebabkan tidak ditemukannya gaya interaksi 'formal' atau 'jauh'. Penelitian ini menunjukkan bahwa tanpa melihat jenis disabilitas, responden kakek-nenek tampak menerapkan gaya interaksi yang sama, meski situasinya berbeda: yaitu sebagai pengganti orangtua, pemberi kesenangan, dan sumber kebijaksanaan keluarga. Yang membedakan adalah konteks, kakek-nenek memberikan dukungan instrumental dan emosional untuk semua cucu mereka dengan cara yang berbeda. Misalnya, dengan cucu-cucu yang tidak menyandang disabilitas, peran dan gaya kakek-nenek yang diterapkan seperti membayar uang sekolah atau membantu pekerjaan rumah, sedangkan untuk cucu-cucu penyandang disabilitas, yaitu dengan menghadiri janji terapi, bantuan mobilitas (Ari, Findler, Noy, \& Zyma, 2016), atau meningkatkan kemampuan komunikasi. Namun begitu, sikap kakek-nenek ini tidak membeda-bedakan cucu,

"saya sama aja ke cucu semuanya, sayang semua...., hanya memang yang satu itu butuh perhatian lebih...”.

Kakek-nenek beradaptasi dengan berbagai situasi unik dalam mendukung keluarga dan cucu mereka. Beberapa masalah dan tantangan yaitu menyangkut hadirnya cucu penyandang disabilitas. Sebagai contoh, kakek-nenek menjelaskan kesulitan dalam mengikuti aturan orang tua dan merawat cucu-cucu dengan disabilitas untuk waktu yang lama (Tepper \& Cassidy, 2006). Namun bagaimanapun, semua subjek menyatakan bahwa mereka berusaha mengikuti aturan orangtua dari cucu disabilitas, berinteraksi dengan ramah dan tidak banyak menegur anak ataupun cucu, serta mengajak silaturahim sebagai salah satu media penting untuk menjaring informasi pengasuhan dan sarana sosialisasi anak disabilitas (Schwartz, Tan, \& Buchanan, 2009).

Seperti pada paparan kutipan berikut:

"saya suka nganterin cucu terapi, atau ke sekolah, sekalian saya jalan-jalan haha...."

"kalo minta pendapat saya, ya...saya kasih saran.. tapi kebanyakan ya diputuskan sendiri, udah pada dewasa kok...".

Kedua pernyataan tersebut membentuk tema superordinat penyedia dukungan sosial bagi keluarga.

Selanjutnya, penelitian jangka panjang harus mengeksplorasi isu-isu lainnya, seperti struktur keluarga, kedekatan, usia dan kebutuhan cucu, cucu-cucu lain dan hubungan kakek-nenek dengan orang tua cucu, yang semuanya bergabung untuk 
mempengaruhi pembentukan identitas dan peran kakek-nenek.

Dari temuan di lapangan, keparahan disabilitas cucu menyebabkan kakek-nenek tidak bisa terlibat terlalu banyak dengan cucu dalam kegiatan sehari-hari. Misalnya, disabilitas parah menyangkut perkembangan keterampilan visual, komunikasi, dan mobilitas yang sangat terbatas. Poin penting dalam hasil riset ini adalah: berbagai bentuk disabilitas cucu membentuk batasan dan harapan tertentu pada kakek-nenek. Dalam penelitian ini, kakek-nenek berinteraksi dengan cara yang sama dengan cucu-cucu mereka, namun interaksi bisa terbatas dan menimbulkan frustrasi jika respon cucu disabilitas sangat rendah. Penelitian selanjutnya bisa mengeksplorasi apakah dan bagaimana sifat disabilitas anak dapat berdampak pada keluarga, khususnya adaptasi kakek-nenek, interaksi dan dampaknya terhadap fisik dan psikologis kakek-nenek serta fungsi sosial keluarga (Kemp, 2007).

Hasil wawancara mengenai hubungan saudara kandung, seperti dalam kutipan berikut:

"kakaknya ngemong (mengasuh) kok....mau nemenin main juga" "ributnya paling kalau adiknya ingin sesuatu, kakaknya gak bisa ngikutin, maklum hehe.."

tergambar kualitas saudara kandung dari cucu disabilitas yang dipersepsi oleh subjek.

Temuan ini konsisten dengan penelitian sebelumnya (Margetts et al. 2006) yang menyoroti bagaimana memenuhi kebutuhan semua anggota keluarga, termasuk orang tua, cucu dengan disabilitas dan cucu lainnya, adalah tindakan menjaga keseimbangan keluarga yang kompleks dan kadang melelahkan bagi kakek-nenek. Kakek-nenek terus berusaha untuk mengembangkan relasi dengan semua cucu, bahkan ketika menghadapi cucu dsisabilitas yang parah, maka kakek-nenek membatasi komunikasi dan relasi pribadi. Merekapun secara aktif memantau dampak disabilitas cucu terhadap cucu lainnya, merawat cucu lain ketika orang tua sibuk dengan kebutuhan anak penyandang disabilitas dan terus berusaha melakukan yang terbaik. Pada tingkat praktis, maka kakek-nenek sering mengesampingkan ambisi individu dan berusaha untuk memainkan peran penting dalam mempertahankan fungsi keluarga (Mason, May, \& Clarke, 2007). Dengan demikian, sangat dibutuhkan suatu program atau intervensi bagi kakek-nenek selain orangtua dan anak disabilitas itu sendiri. Intervensi diharapkan dapat membantu kakek-nenek dalam mendefinisikan peran mereka dan memberi suatu keterampilan untuk berkomunikasi dan berinteraksi dengan cucu disabilitas.

Dalam perjalanan pengasuhan, kakek-nenek berusaha memahami keunikan dari cucu disabilitas, mencoba bersabar dengan perkembangannya yang bisa sangat lambat, dan subjek meyakini bahwa kedekatan emosional dengan cucu tersebut dengan berusaha memahami keterbatasannya, dapat menstimulasi perkembangan cucu disabilitas secara umum. Pada akhirnya, kakek-nenek merasa kedekatannya dengan cucu dan pemberian kasih sayang terhadap cucu disabilitas, mampu menjadikannya sebagai sumber energi dan secara timbak balik dapat membuatnya sehat secara fisik dan psikologis (Komonpaisarn, \& Loichinger, 2018). Namun kakek-nenek ini tetap menghargai perkembangan cucu disabilitasnya tersebut, seperti tercantum dalam hasil wawancara berikut:
"banyak alhamdulillah perkembangannya, dari belum bisa ngomong usia 4 tahun, sekarang sudah lumayan jelas dan banyak ngomong... ya kan terapi terus ya, insyaAllah ada perkembangannya".

Pernyataan ini menunjukkan bahwa terdapat kesesuaian harapan subjek dan keadaan cucunya. Kutipan lainnya, yaitu: "gak apa-apa pelan-pelan berkembangnya, karena emang kan beda-beda ya, ada yang cepat bisa, ada yang butuh lebih lama, yang penting bisa 
sedikit mandiri, dan semakin mandiri...udah senang kami".

Subjek cukup memahami kecepatan perkembangan anak disabilitas yang bersifat unik. Kutipan hasil wawancara berikut:

"ah kalo gak ketemu cucu sebentar aja udah kangen, sedikitnya ingin denger kalo cucu sehat, baik-baik aja gitu...., eyang kan sayang cucu banget"

menunjukkan kedekatan subjek dengan cucu dan cucu disabilitas sebagai sumber kasih sayang.

Hasil penelitian ini memberikan wawasan penting dalam hal identitas kakek-nenek ketika memiliki cucu disabilitas, namun ditemukan beberapa keterbatasan umum yang jadi pertimbangan dalam membahas hasil. Pertama, jumlah sampel relatif kecil dan bersifat eksploratif, terbatas hanya pada pengalaman kakek-nenek di Semarang. Kedua, cucu memiliki beragam disabilitas intelektual, sensorik dan fisik ringan sampai berat, sehingga tentu saja dampaknya akan berbeda terhadap proses pengasuhan. Ketiga, metode pengambilan sampel purposif dengan latar belakang pekerjaan sebelumnya yang berbeda-beda, tanpa pengalaman di bidang medis dan keperawatan, sehingga data hanya mencakup pengasuhan terbatas dan bersifat alami terhadap cucu yang memiliki disabilitas.

\section{SIMPULAN}

Penelitian ini menyoroti pentingnya hubungan kakek-nenek dengan cucu dan peran penting kakek-nenek ketika seorang anak mengalami disabilitas. Hasil riset ini merupakan suatu studi yang secara eksplisit mengeksplorasi bagaimana disabilitas bisa berdampak pada identitas dan peran kakeknenek, dan menunjukkan bahwa pengalaman dan peran kakek-nenek dapat bersifat universal namun tetap sesuai variasi konteks. Sarannya adalah bahwa penelitian selanjutnya dapat mengeksplorasi gaya pengasuhan kakek-nenek dalam kehidupan keluarga, strategi untuk meningkatkan pengalaman hidup positif dari hubungan kakek-nenek- cucu antargenerasi (Olivetti, Paserman, \& Salisbury, 2018), khususnya dengan kehadiran anggota keluarga disabilitas.

\section{DAFTAR PUSTAKA}

Amaro, A. C., Oliveira, L., \& Veloso, A. I. (2016). "Let's build our family tree!": Grandparents and grandchildren using tablets together. Procedia Computer Science, $\quad 100, \quad 619-625$. https://doi.org/10.1016/j.procs.2016.09 .203

Ari, O. T. B., Findler, L., Noy, A., \& Zyma, G. P. (2016). When grandparents drive their grandchildren. Transportation Research Part F: Traffic Psychology and Behaviour, 39, 54-64. https://doi.org/10.1016/j.trf.2016.03.00 4

Australian Bureau of Statistics. (2016). Disability, ageing and carers, Australia: First results, 2015 (Publikasi SDAC No. 4430.0.10.001). Diambil dari

https://www.abs.gov.au/ausstats/abs@ . $\mathrm{nsf} / \mathrm{mf} / 4430.0 .10 .001$

Bangerter, L. R., \& Waldron, V. R. (2014). Turning points in long distance grandparent-grandchild relationships. Journal of Aging Studies, 29, 88-97. https://doi.org/10.1016/j.jaging.2014.0 1.004

Bell, L. K., Perry, R. A., \& Prichard, I. (2018). Exploring grandparents' roles in young children's lifestyle behaviors and the prevention of childhood obesity: An Australian perspective. Journal of Nutrition Education and Behavior, 50(5), 516-521. https://doi.org/10.1016/j.jneb.2017.12. 007

Bol, T., \& Kalmijn, M. (2016). Grandparents' resources and grandchildren's 
schooling: Does grandparental involvement moderate the grandparent effect? Social Science Research, 55, 155-170.

https://doi.org/10.1016/j.ssresearch.201 5.09 .011

Crettenden, A., Lam, J., \& Denson, L. (2018). Grandparent support of mothers caring for a child with a disability: Impacts for maternal mental health. Research in Developmental Disabilities, 76, 35-45. https://doi.org/10.1016/j.ridd.2018.02.0 04

Davey, A., Savla, J., Janke, M., \& Anderson S. (2009). Grandparent-grandchild relationships: From families in contexts to families as contexts. International Journal of Aging and Human Development, 69(4), 311-25.

Desiningrum, D. R. (2018). Grandparents' roles and psychological well-being in the elderly: A correlational study in families with an autistic child. Enfermeria Clinica, 8(1), 44-49.

Di Gessa, G., Glaser, K., \& Tinker, A. (2016). The impact of caring for grandchildren on the health of grandparents in Europe: A lifecourse approach. Social Science \& Medicine, 152, 166-175. https://doi.org/10.1016/j.socscimed.20 16.01 .041

Downie, J. M., Hay, D. A., Horner, B. J., Wichmann, H., \& Hislop, A. L. (2010). Children living with their grandparents: Resilience and wellbeing. International Journal of Social Welfare, 19(1), 8-22. DOI: $10.1111 / \mathrm{j} .1468-$ 2397.2009.00654.x

Dunne, E. G., \& Kettler, E. J. (2008). Grandparents raising grandchildren in Australia: Exploring psychological health and grandparents' experience of providing kinship care. International Journal of Social Welfare, 17(4), 333-
$345 . \quad$ DOI: $\quad 10.1111 / \mathrm{j} .1468-$ 2397.2007.00529.x

Falk, U., \& Falk, G. (2002). Grandparents: A new look at the supporting generation. New York: Prometheus Books.

Gitlin, L. N., Winter, L., Dennis, M. P., Hodgson, N., \& Hauck, W. W. (2010) A biobehavioral home-based intervention and the well-being of patients with dementia and their caregivers: The COPE randomized trial. JAMA, 304(9), 983-991.

Goh, E. C. L. (2009). Grandparents as childcare providers: An in-depth analysis of the case of Xiamen, China. Journal of Aging Studies, 23(1), 60-68. https://doi.org/10.1016/j.jaging.2007.0 8.001

He, Q., Li, X., \& Wang, R. (2018). Childhood obesity in China: Does grandparents' coresidence matter? Economics \& Human Biology, 29, 56-63. https://doi.org/10.1016/j.ehb.2018.02.0 01

Hens. (2016). Genetic testing and counseling in the case of an autism diagnosis: A caregiver's perspective. European Journal of Medical Genetics, 59, 452458.

Hofstede, G., Hofstede, G. J., \& Minkov, M. (2010). Cultures and organizations (3rd ed.). New York: Mc GrawHill.

Keeling, S. (2012). Grandchildren's perspectives on grandparents in rural New Zealand. Journal of Rural Studies, 28(4),

371-379. https://doi.org/10.1016/j.jrurstud.2012. 04.002

Kelley, S. J., Whitley, D. M., \& Peter, E. (2011). Behavior problems in children raised by grandmothers: The role of caregiver distress, family resources, and the home environment. Children and 
Youth Services Review, 33(11), 21382145.

https://doi.org/10.1016/j.childyouth.20 11.06.021

Kemp, C. L. (2007). Grandparent-grandchild ties: Reflections on continuity and change across three generations. Journal of Family Issues, 28(7), 855-881.

Komonpaisarn, T., \& Loichinger, E. (2018). Providing regular care for grandchildren in Thailand: An analysis of the impact on grandparents' health. Social Science \& Medicine, 229, 117125.

https://doi.org/10.1016/j.socscimed.20 18.05.031

Mahne, K., \& Klingebiel, A. M. (2012). The importance of the grandparent role-A class specific phenomenon? Evidence from Germany. Advances in Life Course Research, 17(3), 145-155. https://doi.org/10.1016/j.alcr.2012.06.0 01

Margetts, J. K, Le Couteur, A., \& Croom, S. (2006). Families in a state of flux: The experiences of grandparents in autism spectrum disorder. Child: Care, Health and Development, $32(5)$, 565-574. https://doi.org/10.1111/j.13652214.2006.00671.x

Mason, J., May, J., \& Clarke, L. (2007). Ambivalence and the paradoxes of grandparenting. The Sociological Review, 55(4), 687-706.

Olivetti, C., Paserman, M. D., \& Salisbury, L. (2018). Three-generation mobility in the United States, 1850-1940: The role of maternal and paternal grandparents. Explorations in Economic History, 70, 73-90. https://doi.org/10.1016/j.eeh.2018.07.0 01
Reitzes, D. C., \& Mutran, E. J. (2004). Grandparent identity, intergenerational family identity, and well-being. The Journals of Gerontology: Psychological Sciences and Social Sciences, 59(4), S213-S219.

Rogers, E., Bell, L., \& Mehta, K. (2019). Exploring the Role of Grandparents in the Feeding of Grandchildren Aged 1-5 Years. Journal of Nutrition Education and Behavior, 51(3), 300-306. https://doi.org/10.1016/j.jneb.2018.08. 016

Rosenbaum, P. (2016). Developmental disability: Shouldn't grandparents have a place at the table? Developmental Medicine and Child Neurology, 58(6), 528.

http://dx.doi.org/10.1111/dmcn.13125

Schwartz, S. A., Tan, J. P., \& Buchanan, A. (2009). Adolescents' perspectives on relationships with grandparents: The contribution of adolescent, grandparent, and parent-grandparent relationship variables. Children and Youth Services Review, 31(9), 1057-1066. https://doi.org/10.1016/j.childyouth.20 09.05.007

Sims, M., \& Rofail, M. (2013). The experiences of grandparents who have limited or no contact with their grandchildren. Journal of Aging Studies, 27(4), 377-386. https://doi.org/10.1016/j.jaging.2013.0 9.002

Smith, J. A., Flowers, P., \& Larkin, M. (2009). Interpretative phenomenological analysis: Theory, method, and research. London: Sage Publications.

Smorti, M., Tschiesner, R., \& Farneti, A. (2012). Grandparents-Grandchildren Relationship. Procedia - Social and Behavioral Sciences 46, 895-898. 
https://doi.org/10.1016/j.sbspro.2012.0 5.219

Snopkowski, K., \& Sear, R. (2015). Grandparental help in Indonesia is directed preferentially towards needier descendants: A potential confounder when exploring grandparental influences on child health. Social Science \& Medicine. 128, 105-114. https://doi.org/10.1016/j.socscimed.20 15.01.012

Szinovacz, M. E., \& Davey, A. (2006). Effects of retirement and grandchild care on depressive symptoms. The International Journal of Aging and Human Development, 62(1), 1-20. https://doi.org/10.2190/8Q46-GJX4M2VM-W60V

Tepper, C. A., \& Cassidy, K. (2006). A review of: "Multidisciplinary perspectives on aging". Educational Gerontology, 32(7), 599-601. https://doi.org/10.1080/036012706007 23817
Villar, C. D. (2015). Correlations between cultural orientations and successful aging of Filipino elders. Journal of Media and Communication Study, 7(7), 122-144. https://doi.org/10.5897/JMCS2015.045 3

Woodbridge, S., Buys, L., \& Miller, E. (2009). Grandparenting a child with a disability: An emotional rollercoaster. Australasian Journal on Ageing 28, 3740.

Woodbridge, S., Buys, L., \& Miller, E. (2011). 'My grandchild has a disability': Impact on grandparenting identity, roles and relationships. Journal of Aging Studies, 25, 355-363

Xu, H. (2018). Physical and mental health of Chinese grandparents caring for grandchildren and great-grandparents. Social Science \& Medicine, 229, 106111. https://doi.org/10.1016/j.socscimed.20 18.05.047 